Revista Eletrônica do Mestrado em Educação Ambiental

\title{
Um canto de resistência: imagens do desfile da Mangueira de 2019 em diálogo com a educação
}

\author{
Jonas Alves da Silva Junior ${ }^{1}$ \\ Universidade Federal Rural do Rio de Janeiro \\ https://orcid.org/0000-0002-7809-5164
}

Resumo: O enredo da Estação Primeira de Mangueira de 2019 trouxe à baila heróis e heroínas ignorados/as pela história oficial e, por consequência, ausentes nos livros didáticos e no currículo escolar. A possibilidade de dar lugar a esse avesso de nossa narrativa toca nos pressupostos da formação escolar, uma vez que somos formados com base nas referências das classes hegemônicas. Por isso, problematizar essa questão, em diálogo com o que se propõe no desfile da Mangueira, é o objetivo deste ensaio. Para nos ajudar a percorrer as complexas e coloridas alas deste desfile de ideias, recorremos às elucubrações sobre narrativa em Benjamin; e no conceito de necropolítica de Mbembe. Analisar a potente apresentação visual da Mangueira, em diálogo com a Educação, pode contribuir para a reflexão de uma escola calcada nos Direitos Humanos, na democracia e na justiça social.

Palavras-chave: Educação; Direitos Humanos; Estação Primeira de Mangueira.

\section{Canción de resistencia: imágenes de la Mangueira desfile 2019 en diálogo con educación}

Resumen: La trama de la escuela de samba de Mangueira de 2019 puso de manifiesto héroes y heroínas ignorados por la historia oficial y, en consecuencia, ausentes en los libros de texto y en el plan de estudios de la escuela. La posibilidad de dar paso a este reverso de nuestros toques narrativos sobre los supuestos de la educación escolar, ya que estamos formados en base a las

${ }^{1}$ Possui graduação em Letras (USP) e em Pedagogia (Uninove); Mestrado em Letras pela USP; especialização em Arteeducação pela UnB e Doutorado e Pós-doutorado em Educação pela USP. Professor Adjunto do Departamento de Educação e Sociedade (DES) e do Programa de Pós-Graduação em Educação, Contextos Contemporâneos e Demandas Populares (PPGEduc) da Universidade Federal Rural do Rio de Janeiro (UFRRJ).É líder do LEGESEX - Laboratório de Estudos de Gênero, Educação e Sexualidades (UFRRJ/CNPq). Coordena também a linha de pesquisa Gênero, Sexualidade, Infâncias e Educação (GRUPIs/CNPq). Suas investigações versam sobre corpos, sexualidades e gênero na escola, na perspectiva da Educação em Direitos Humanos. e-mail: jonasjr@usp.br

Rev. Eletrônica Mestr. Educ. Ambient. Rio Grande, Dossiê temático "Imagens: resistências e criações cotidianas", p.368-387, jun. 2020. E-ISSN 1517-1256 
referencias de las clases hegemónicas. Por lo tanto, problematizar este tema, en diálogo con lo que se propone en el desfile de Mangueira, es el objetivo de este ensayo. Para ayudarnos a navegar por las alas complejas y coloridas de este desfile de ideas, recurrimos a las explicaciones narrativas de Benjamin; y el concepto de neberopolítica de Mbembe. Analizar la poderosa presentación de Mangueira, en diálogo con la Educación, puede contribuir a la reflexión de una escuela basada en los Derechos Humanos, la democracia y la justicia social.

Palabrasllave: Educación; Derechos humanos; Manguera

\title{
Resistance samba: images of the Mangueira parade of 2019 in dialogue with education
}

\begin{abstract}
The plot of the Mangueira samba school of 2019 brought to the fore heroes and heroines ignored by the official history and, consequently, absent in textbooks and in the school curriculum. The possibility of giving way to this reverse of our narrative touches on the assumptions of school formation, since we are formed based on the references of the hegemonic classes. Therefore, problematizing this issue, in dialogue with what is proposed in the Mangueira parade, is the objective of this essay. To help us navigate the complex and colorful wings of this parade of ideas, we resorted to Benjamin's narrative explanations; and Mbembe's concept of necropolitics. Analyzing the powerful presentation of Mangueira, in dialogue with Education, can contribute to the reflection of a school based on Human Rights, democracy and social justice.
\end{abstract}

Keywords: Education; Human rights; Hose.

\section{Abre-alas}

É preciso escovar a história a contrapelo.

Walter Benjamin

Inicio este texto evocando Walter Benjamin (2018), quando, na obra "A arte de contar histórias", ele afirma que a experiência transmitida pela oralidade é a nascente de onde vieram todos os contadores de histórias. É possível que Leandro Vieira, carnavalesco da escola de samba Mangueira, ao conceber o enredo "História para ninar gente grande" (2019) recorreu a essa fonte quando se propôs a escutar os gritos que não foram "ouvidos" nos livros oficiais. Até porque, ao contarem suas experiências de geração para geração, boa parte das histórias que a agremiação levou para a avenida só chegou ao nosso conhecimento graças à tradição oral, encampada pelos nossos antepassados. A contação de histórias se configura na preservação dessas experiências.

De acordo com a apresentação do enredo presente no site oficial da escola ${ }^{2}$, "História para ninar gente grande" é considerada pelo carnavalesco como um enredo histórico, cuja proposta é:

\footnotetext{
${ }^{2}$ Disponível em http://www.mangueira.com.br/noticia-detalhada/993 . Acesso em 13 abr. 2020
}

Rev. Eletrônica Mestr. Educ. Ambient. Rio Grande, Dossiê temático "Imagens: resistências e criações cotidianas", p.368-387, jun. 2020. E-ISSN 1517-1256 
questionar acontecimentos históricos cristalizados no imaginário coletivo e que, de alguma forma, nos definem enquanto nação. Essas ideias de "descobrimento", "independência" e "abolição" postas em cheque ou questionadas para possibilitar o entendimento do desprezo pela cultura nacional e as razões de uma sociedade pacífica ou, porque não, passiva. (VIEIRA, 2018, s/p)

Desta forma, o enredo da Estação Primeira de Mangueira de 2019 trouxe à baila heróis e heroínas ignorados/as pela história oficial e, por consequência, ausentes nos livros didáticos e no currículo escolar. Mulheres, índios/as, negros/as, pobres, gays, lésbicas, pessoas trans... uma lista de sujeitos que foram sistematicamente apagados/as da história, para que a manutenção da hegemonia branca, cisheteronormativa, patriarcal e cristã se mantivesse no topo da pirâmide social.

Assim, o desfile da Mangueira revisita a história, atribuindo o protagonismo a quem lhe é de direito: "Marias, Mahins, Marielles, Malês". Disso, vem à tona massacres, genocídios, violências que a população marginalizada sofreu no Brasil desde a invasão portuguesa, em 1500. Direitos Humanos para quê? Ou melhor, para quem? Nossa história traz um vasto e triste cardápio de práticas em que os Direitos Humanos são sumariamente ignorados. Nesse sentido, de que forma a escola pode dar lugar a essa história que a

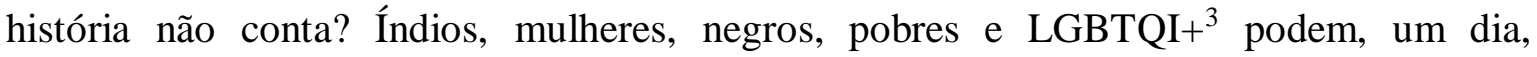
estampar livros e estar presentes no currículo oficial da escola?

A possibilidade de dar lugar a esse avesso de nossa narrativa, no que tange à escola, toca na questão da formação docente, uma vez que professores/as ainda são formados/as com base nos interesses das classes hegemônicas (SILVA, 2007). Por isso, essa questão, em diálogo com o que se propõe no desfile da Mangueira, é o nosso objetivo neste ensaio. Para tal, o texto está dividido em 4 sessões: 1) descrição e análise do desfile da Mangueira de 2019; 2) ataque aos Direitos Humanos no Brasil contemporâneo; 3) reverberações e possibilidades de outras "narrativas oficiais" na escola, a partir do trabalho com imagens da linguagem audiovisual; 4) considerações finais.

\section{Brasil, meu dengo, a Mangueira chegou}

Desde 2016, quando o carnavalesco Leandro Vieira se instalou na Estação Primeira de Mangueira, a escola tem feito desfiles arrebatadores e de contundente crítica social. Já em seu primeiro desfile pela escola, foi campeão com o enredo sobre a cantora Maria

\footnotetext{
${ }^{3}$ Lésbicas, gays, bissexuais, travestis/transexuais, queers, intersexuais.

Rev. Eletrônica Mestr. Educ. Ambient. Rio Grande, Dossiê temático "Imagens: resistências e criações cotidianas", p.368-387, jun. 2020. E-ISSN 1517-1256
} 
Bethânia ("A menina dos olhos de Oyá"). Nos dois anos seguintes, apresentou narrativas críticas sobre a intolerância religiosa ("Só com a ajuda do santo", 2017) e sobre a gestão municipal do Rio de Janeiro que visava contingenciar verbas e criar obstáculos para o desfile das escolas de samba ("Com dinheiro ou sem dinheiro, eu brinco!", 2018). Nessas três oportunidades, a escola fez desfiles de impacto e de boa comunicação com o público, o que a fez voltar ao desfile das campeãs ${ }^{4}$ por três anos consecutivos.

Por conta do bom retrospecto, havia certa expectativa do que a Mangueira apresentaria no desfile de 2019. E essa expectativa só aumentou quando, em 14 de outubro de 2018, foi anunciado o samba vencedor que seria entoado no próximo cortejo da escola.

Para além das qualidades da letra e melodia do samba, o que imediatamente chamou atenção da mídia na época foi a menção à figura da vereadora assassinada Marielle Franco. Seguem algumas manchetes sobre o fato: "Mangueira homenageia Marielle Franco em letra de samba do Carnaval 2019" (JCONLINE, 15/10/2018). "Com 'samba da Marielle', Mangueira exaltará heróis esquecidos nas placas de rua" (SETOR 1/BAND, 15/10/2018). "Mangueira anuncia samba-enredo em homenagem à Marielle e mulheres que lutaram por direitos" (GELEDÉS, 16/10/2018). "Mangueira divulga samba-enredo que homenageará Marielle Franco" (O POVO, 14/10/2018). "Mangueira escolhe samba do Carnaval de 2019 e homenageia Marielle Franco" (G1 RIO, 14/10/2018). "Mangueira faz homenagem a Marielle em samba-enredo de 2019" (DIÁRIO DE PERNAMBUCO, $14 / 10 / 2018)$.

No entanto, a repercussão não ficou circunscrita somente à homenagem a Marielle na letra, pois, ao ser lançado o disco com os sambas de enredo do carnaval 2019 do Rio de Janeiro, logo a Mangueira despontou, entre os/as especialistas, como o melhor samba da safra. Vejamos o que disseram alguns sambistas e pesquisadores/as de carnaval: "Espetacular é pouco para resumir esta obra-prima da verde e rosa. O enredo que valoriza os heróis esquecidos da história do país tem um samba fabuloso e fidalgamente necessário" (FONSECA, Carlos Alberto. 2019. Sambario).

O samba mais badalado do pré-carnaval, a meu ver, tem o seu apelo emocional muito calcado pelos acontecimentos políticos no Brasil. Diante da eleição de um governo de proposta polêmica em relação aos direitos humanos, um samba que exalta Marielle Franco, vereadora que foi assassinada por seu ativismo, acabou unindo pessoas tocadas pela indignação contra todo este momento pavoroso em que vivemos. De certa

\footnotetext{
${ }^{4}$ As seis agremiações do Grupo Especial com melhor classificação voltam a desfilar no sábado pós-quarta-feira de cinzas, no dia que é chamado de Desfile das Campeãs. A primeira escola a entrar na avenida é sempre a $6^{\mathrm{a}}$ colocada. E a última, é sempre a campeã.
}

Rev. Eletrônica Mestr. Educ. Ambient. Rio Grande, Dossiê temático "Imagens: resistências e criações cotidianas", p.368-387, jun. 2020. E-ISSN 1517-1256 
forma, o samba acaba acertando o sentimento do enredo - é o sambista escrevendo sua própria história, escolhendo seus heróis, levantando sua bandeira. (MARCOS, João. 2019. Sambario)

O samba oficial da Mangueira já fez um grande sucesso logo que foi divulgado. Mas também gerou polêmica, pois cita Marielle Franco, vereadora assassinada no Rio de Janeiro no ano passado. Muitos acharam que ela não deveria ser citada. Outros consideraram bastante válida a sua inclusão na obra. Houve uma comoção, principalmente nas redes sociais, para que o samba fosse escolhido. E foi o que a escola fez. Ele tomou uma proporção tão grande que está sendo executado em blocos, bandas, bares, rodas de samba e até no metrô, coisa que não costuma acontecer com tanta antecedência e amplitude. $\mathrm{O}$ samba é excelente, possui uma letra muito inspirada, com diversas passagens impactantes. A melodia também é bonita e dá o tom necessário para o desfile da escola. Muitos consideram o melhor samba de 2019. (SOARES, Rafael. 2019. Artecult)

De fato, a repercussão do samba da Mangueira foi enorme, não só pela referência a Marielle Franco na letra, mas também pela qualidade da obra, o que rendeu todas as notas 10 dos/das jurados/as na Sapucaí e arrebatou o renomado prêmio Estandarte de Ouro (concedido pelo jornal O Globo) como melhor escola e melhor samba-enredo, sem contar que foi a grande campeã do Grupo Especial do carnaval 2019, ganhando com vantagem de 3 décimos em relação à segunda colocada, que foi a Unidos do Viradouro.

A Estação Primeira de Mangueira foi a $6^{\text {a }}$ agremiação a desfilar na segunda noite das escolas do Grupo Especial do Rio de Janeiro, no dia 04/03/2019, e precisou de 71 minutos para apresentar a "História para ninar gente grande". Com o intuito de recontar a história do Brasil, a escola iniciou seu desfile com uma apresentação de comissão de frente que foi capaz de sintetizar o enredo. Em um primeiro momento, os heróis consagrados das páginas oficiais da história surgiam emoldurados dentro de um tripé. No chão, bailarinos/as representando índios/as e negros/as realizavam uma coreografia.

Já na segunda parte, os/as personagens anônimos/as adentram no tripé e arrancam os "heróis" das molduras. Quando saem, percebemos que são representados como anões. Os novos heróis, então, rasgam a página de um livro de história. Nesse momento, aparece uma criança. Ela ergue uma faixa em que está escrito a palavra "Presente", em clara alusão ao assassinato da vereadora Marielle Franco. Mas não só. A faixa, aberta logo no início do desfile, por uma menina negra em idade escolar, anuncia que, naquele desfile, o povo, representado sobretudo por mulheres, negras/os e índias/os serão representados não como derrotados, mas como heróis de uma nação. Em contrapartida, a Princesa Isabel, o bandeirante Domingos Jorge Velho, o Marechal Deodoro da Fonseca, o imperador D. Pedro I, o missionário José de Anchieta e o “descobridor" Pedro Álvares Cabral são 
extirpados da moldura para revelar o real tamanho de suas ações. Assim, no "avesso desse mesmo lugar", inscreveu-se a grandeza de negros/as e índios/as, delineando sua importância para as futuras gerações.

O carnavalesco Leandro Vieira, seguindo a estética que iniciara em 2016 com o enredo sobre a cantora Maria Bethânia, mais uma vez trouxe uma proposta transgressora. O primeiro setor, intitulado "Mais invasão que descobrimento" tratou de explicitar o óbvio: que não houve o descobrimento do Brasil, mas, sim, uma invasão capitaneada pelos europeus.

A utilização do termo 'descobrimento' está ligada ao etnocentrismo dos portugueses e também dos europeus. Por entenderem o mundo tendo por centro sua própria etnia, seu próprio povo, os portugueses desconsideraram que os indígenas já conheciam o território. Eles foram os primeiros europeus a conhecerem a localidade. $\mathrm{O}$ descobrimento refere-se, então, aos povos da Europa, e não aos povos que já habitavam o continente americano. (LIESA, 2019, p. 316)

No segundo setor, "Heróis de lutas inglórias", a história indígena continuou sendo narrada, denunciando o genocídio que os nativos sofreram pelas mãos dos ditos "heróis".

É nesse contexto que a abordagem conceitual do setor apresenta personagens como Cunhambebe e Sepé Tiaraju, que lideraram movimentos de resistência indígena, como a Confederação dos índios tamoios e a Guerra Guaranítica, respectivamente. Apresenta também episódios marcantes da história indígena, como a Confederação dos índios Cariris e a Guerra de Independência da Bahia, e a presença dos caboclos que lutaram no dois de julho. (LIESA, 2019, p. 317)

No terceiro setor, "Nem do céu, nem das mãos de Isabel", a escola desconstruiu a representação de heroína da princesa Isabel. O fim da escravidão no Brasil, de um modo geral, é apresentado como uma ação do Estado brasileiro que resultou na assinatura da Lei Áurea em 1888, delegando pouco, ou nenhum espaço, para o registro do papel desempenhado pelas lutas dos negros como principal forma de pressão pelo fim da escravidão. Com base nessa premissa, personalidades como de José Piolho, Tereza de Benguela, Esperança Garcia, Manoel Congo, Marianna Crioula, Acotirene, Luís Gama, entre outros, são apresentados ao longo do desfile.

No setor seguinte, "A história que a história não conta", o enredo satirizou heróis da Monarquia. Duque de Caxias, Marechal Deodoro, Floriano Peixoto, dentre outros, vêm representados de forma caricata.

Como se sabe, heróis são símbolos de identificação coletiva. Personalidades reconhecidas através de seus feitos, por um território, ocorrendo entre eles, uma identificação. A priori, existem dois tipos distintos de herói: os que nascem de forma espontânea, a partir do

Rev. Eletrônica Mestr. Educ. Ambient. Rio Grande, Dossiê temático "Imagens: resistências e criações cotidianas", p.368-387, jun. 2020. E-ISSN 1517-1256 
reconhecimento popular de seus feitos emblemáticos, e aqueles de menor impacto, desprovidos de tanto heroísmo, dependentes quase como regra de "um empurrãozinho" para a promoção da figura. É nesse último perfil que se encaixa a seleção de personagens históricos apresentados ao longo das alas e na alegoria que encerra o setor. (LIESA, 2019, p. 318)

Desta forma, em sequência, as alas vão desconstruindo a representação heroica atribuída a personalidades como o "descobridor" Pedro Álvares Cabral, o imperador Pedro I e o Marechal Deodoro da Fonseca, até chegar a exemplar figura do alferes Joaquim José da Silva Xavier (Tiradentes), um paradigma de como os mitos podem ser criados com base em uma construção seletiva e programada.

O desfile foi encerrado com o setor "Dos Brasis que se faz um país" e jogou luz sobre a necessidade de se compreender a verdade do passado para construir o futuro. Assim, a obra celebra a identidade popular com base no conceito artístico e estético do setor ao qual assinala a beleza e a arte produzidas pelo povo, que são as riquezas mais potentes e expressivas do país.

Benjamin (1987, p. 72) pondera que "a verdadeira imagem do passado perpassa, veloz. O passado só se deixa fixar como imagem que relampeja irreversivelmente, no momento em que é reconhecido". Por isso, o que o cortejo da Estação Primeira de Mangueira propôs não foi apenas recuperar o passado. O que se viu não delineou somente o resgate desse passado como a representação de um tempo inerte; como se o enredo apenas sugerisse um retorno ao passado, transmutando uma compreensão por outra. $\mathrm{O}$ desfile da agremiação sugeria mais que uma urgente visibilidade dos gritos que foram sufocados; propunha, sim, uma retomada desses clamores. Essas concepções foram representadas visualmente, sobretudo, na segunda e quinta alegoria.

"O sangue retinto por trás do herói emoldurado" - segundo carro alegórico da agremiação - trouxe a representação do Monumento às Bandeiras, situado na cidade de São Paulo, atualizando a história negligenciada, por intermédio de pichações na cor vermelha de expressões como "ladrões" e "assassinos"; e, na parte de baixo do monumento, era possível avistar esqueletos que simbolizavam mulheres e índios tamoios e tupinambás assassinados. Sobre isso, Benjamin (1987, p. 36) afiança em seus estudos que "nunca houve um documento da cultura que não fosse simultaneamente um documento da barbárie", e é exatamenteessa concepção que a Mangueira evidencia na alegoria.

No quinto carro alegórico, "A história que a história não conta”, é apresentada essa mesma concepção, com os "heróis" enquadrados pela história, sambando sobre os corpos chacinados. A agremiação, propositalmente, concebeu um visual oposto ao que 
comumente se vê nos livros didáticos, e ao que foi desenvolvido em nossa formação escolar. Assim, esses "heróis" não são apresentados em cenas de status e glória, mas, sim, caracterizados como genocidas, como devastadores de histórias e de culturas populares. E o que é ainda mais assustador é que essas narrativas continuam negligenciadas à sombra da oficialidade. Diversos feitos de índios/as, negros/as, mulheres, LGBTQI+ e pobres ficam à margem das grandes mídias, para que figuras que representam a preservação do poder de um grupo racista, sexista, xenofóbico e LGBTQIfóbico tenham sempre visibilidade e prestígio.

O encerramento do desfile ficou por conta de uma ala cujos componentes carregavam a bandeira do Brasil ressignificada. Trata-se de uma representação em que os paradigmas foram todos rompidos: no lugar das cores oficiais verde e amarelo da bandeira, o emblemático verde e rosa de Mangueira; e onde haveria a máxima "ordem e progresso", vem escrito "índios, negros e pobres". Com isso, a agremiação sugestiona que não existe a possibilidade de acatar uma ideia de progresso com base em uma narrativa unilateral. É necessário reconfigurar a cronologia, a linearidade, para que o porvir seja resultado das disputas de poder do passado e do presente dessas populações que foram marginalizadas por uma hegemonia que assassina a diversidade e as diferenças.

\section{Tem sangue retinto pisado atrás de um herói emoldurado}

Para além da qualidade técnica e estética do desfile da Mangueira de 2019, o que impulsionou o sucesso e a repercussão da "História para ninar gente grande", certamente é o momento histórico-político-cultural em que estamos envolvidos atualmente, sobretudo a partir de 2017, quando políticas de morte e ódio - necropolítica ${ }^{5}$ - iniciaram ataques sistemáticos a populações específicas, como mulheres, negros/as, índios/as e LGBTQI+. Como forma de efetivação dessa política, três campos estão sendo sistematicamente atacados: Arte, Educação e Ciência. Assim, em nome de uma política que se assenta numa agenda moral, exposições artísticas, obras de arte, peças teatrais têm sido canceladas ou sua execução dificultada pelo poder público. Exemplo disso foi o cancelamento da exposição brasileira "Queer Museu- Cartografias da diferença na arte”, em Porto Alegre, em 2017.

Na escola, desde que o Kit "Brasil sem Homofobia" foi vetado pelo governo Dilma, em 2011, o patrulhamento ao docente só tem aumentado. Por isso, projetos de lei, como o

\footnotetext{
${ }^{5}$ Este conceito será abordado neste texto.

Rev. Eletrônica Mestr. Educ. Ambient. Rio Grande, Dossiê temático "Imagens: resistências e criações cotidianas", p.368-387, jun. 2020. E-ISSN 1517-1256
} 
Escola Sem Partido, que representam o professor como doutrinador e, por isso, passível de punição, ganham força por todo o país. Já na Ciência, o contingenciamento de verba para universidades públicas e institutos de pesquisa, articulado à difamação de dados e estudos científicos, vêm paulatinamente estrangulando e desacreditando a pesquisa no Brasil, no intuito de abrir uma "avenida" para o senso comum e o obscurantismo. Para justificar tais ações, a atual política de estado afirma que Direitos Humanos não são para todos. E que políticas públicas devem ser pensadas para a maioria.

Como resultado dessa necropolítica, Brasil e Colômbia travam a infeliz disputa pela primeira posição de país mais perigoso do mundo para ser um/a ativista de Direitos Humanos, de acordo com o relatório "Basta de assassinatos" (2018), editado pela organização Front Line Defenders. Se se referir a terra ou meio ambiente, Colômbia é a nação mais violenta; se se tratar dos direitos das mulheres ou população LGBTQI+, o Brasil encabeça as estatísticas de homicídios.

O limiar entre os vetores dos Direitos Humanos configura-se numa tentativa de sistematizar onde estão as temáticas de maior ameaça em cada país. No entanto, histórias reais de ativistas coagidos/as ou assassinados/asevidenciam como o limite é impreciso, como, por exemplo, o caso Marielle Franco. Como precisar os limites de luta da vereadora carioca assassinada? Ações calcadas nas lutas feministas ou em lideranças comunitárias? Essas são indagações obtusas para entender a multiplicidade da agenda de Direitos Humanos hoje, sobretudo na América Latina.

Há uma junção contínua de vidas precárias que faz com que algumas lideranças políticas se tornem mais vulneráveis. Achille Mbembe (2018) descreve tal fato como necropolítica: políticas de morte para o domínio das populações. O autor recorre a Michel Foucault, especificamente na última aula do curso "Em defesa da sociedade", de 1976. Nesta obra, Foucault (2000) argumenta em prol de um entendimento de como o racismo de Estado seria um dos mecanismos do biopoder e da biopolítica. Com base no poder de "fazer viver e deixar morrer", o racismo de Estado fixaria os requisitos de permissividade para quem vive e para quem morre. Nesse sentido, Mbembe (2018) avança ao evidenciar como o biopoder é deficiente para depreender as relações de hostilidade e perseguição contemporâneas, uma vez que existe uma necropolítica em vigor para engendrar os "mundos de morte".

A história de Marielle Franco - mulher negra, lésbica e advinda da favela - acabou por se tornar uma alegoria do que acontece na América Latina, cujas mudanças políticas são tratadas como movimento conservador, populista ou cristão. Mudanças essas que se Rev. Eletrônica Mestr. Educ. Ambient. Rio Grande, Dossiê temático "Imagens: resistências e criações cotidianas", p.368-387, jun. 2020. E-ISSN 1517-1256 
configuram em táticas da necropolítica para delimitar o que "pode fazer viver e o que pode deixar morrer” (MBEMBE, 2018, p. 24). Quanto mais vulneráveis forem as populações, como as mulheres, sobretudo as negras; população indígena; pessoas com deficiência; negros; comunidade LGBTQI+, maior a discrepância entre o poder da vida e da morte. Não é por mera casualidade que "feminicídio" foi um termo inicialmente difundido pelas mulheres do Hemisfério Sul, da mesma forma que não é coincidência ser cada vez mais perigoso uma mulher atuar no ativismo de Direitos Humanos, especialmente no Brasil (FRONT LINE DEFENDERS, 2018, p. 6).

As articulações de inimizade, conforme afirma Mbembe (2018), dinamizam-se pelo poder de matar, "definem cortes de aceitabilidade para tirar uma vida", implantando os governos de medo e instabilidade. Quando a ação do Estado projeta a necropolítica como gerência de comando das populações, passamos a retratar o caos como "emergência", "conflito" ou "crise humanitária" (MBEMBE, 2018). Acontece que os mecanismos de exclusão e repressão já estavam instituídos bem antes de serem nomeadas pela semântica do horror.

Retornando ao desfile da Estação Primeira de Mangueira de 2019, a última alegoria do cortejo, "A história que a história não conta" consegue sintetizar o momento político obscuro em que vive o Brasil. Vejamos algumas imagens do carro:

Imagem 1: Visão panorâmica do carro alegórico "A história que a história não conta"

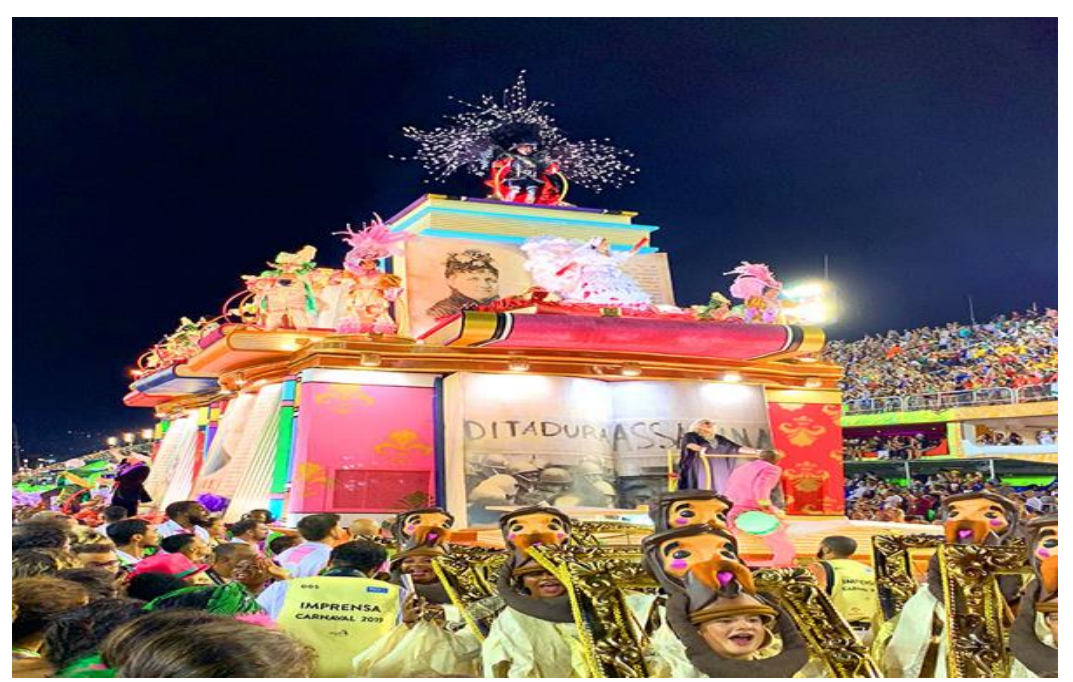

Rev. Eletrônica Mestr. Educ. Ambient. Rio Grande, Dossiê temático "Imagens: resistências e criações cotidianas", p.368-387, jun. 2020. E-ISSN 1517-1256 
Imagem 2: Destaque do carro - Hildegard Angel

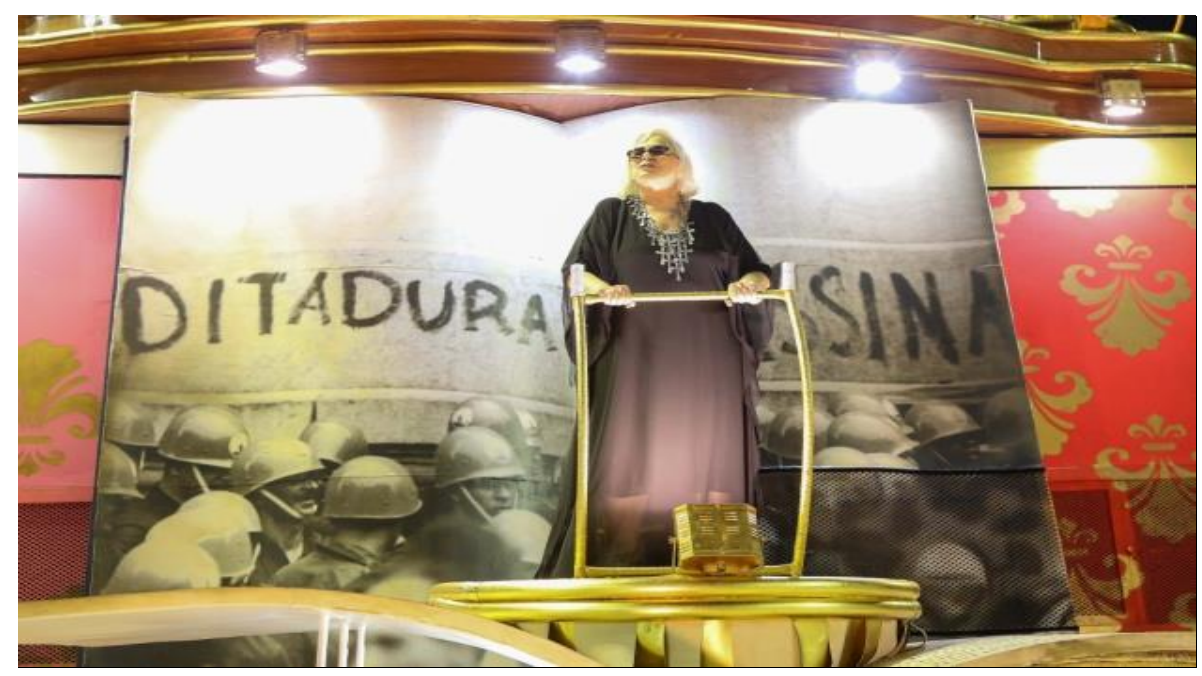

Imagem 3: Livros abertos, com a reescrita da História

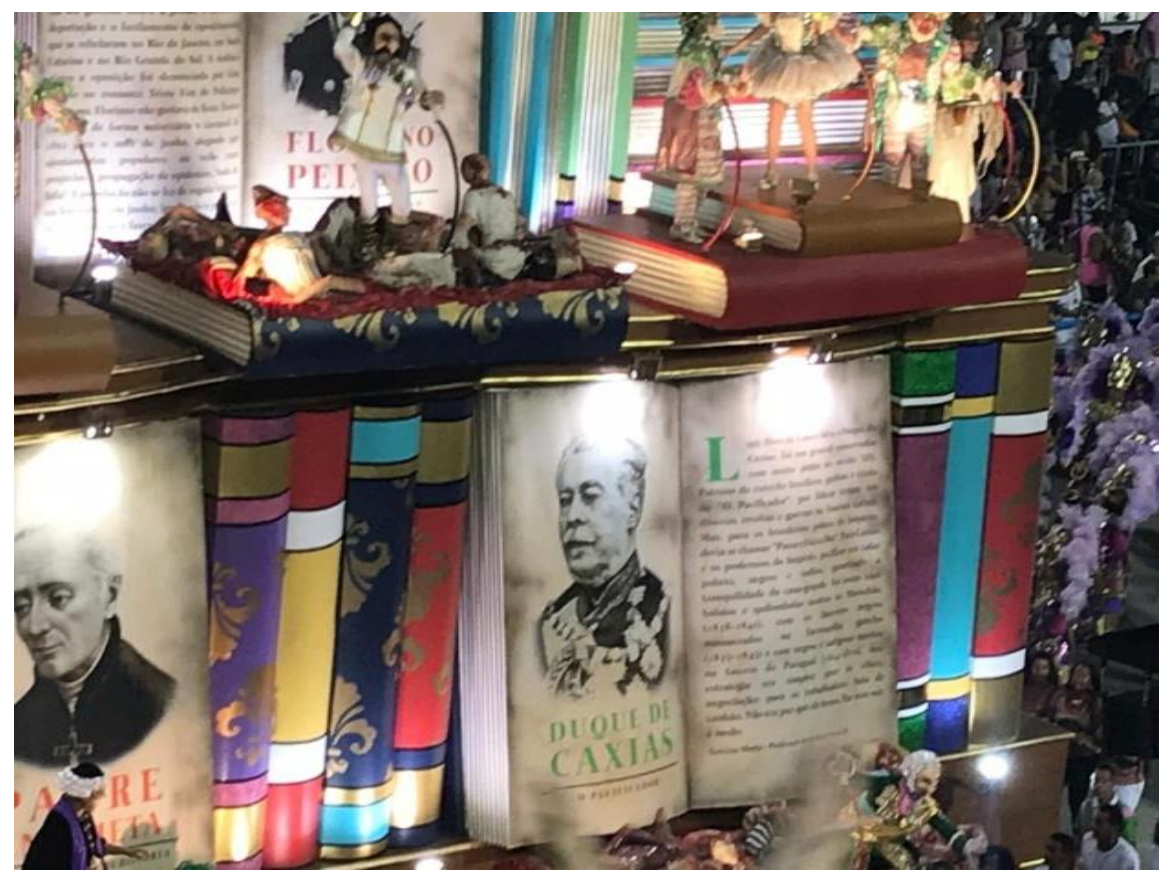

Rev. Eletrônica Mestr. Educ. Ambient. Rio Grande, Dossiê temático "Imagens: resistências e criações cotidianas", p.368-387, jun. 2020. E-ISSN 1517-1256 
Imagem 4: “Herói” Duque de Caxias sambando em cima de corpos mortos

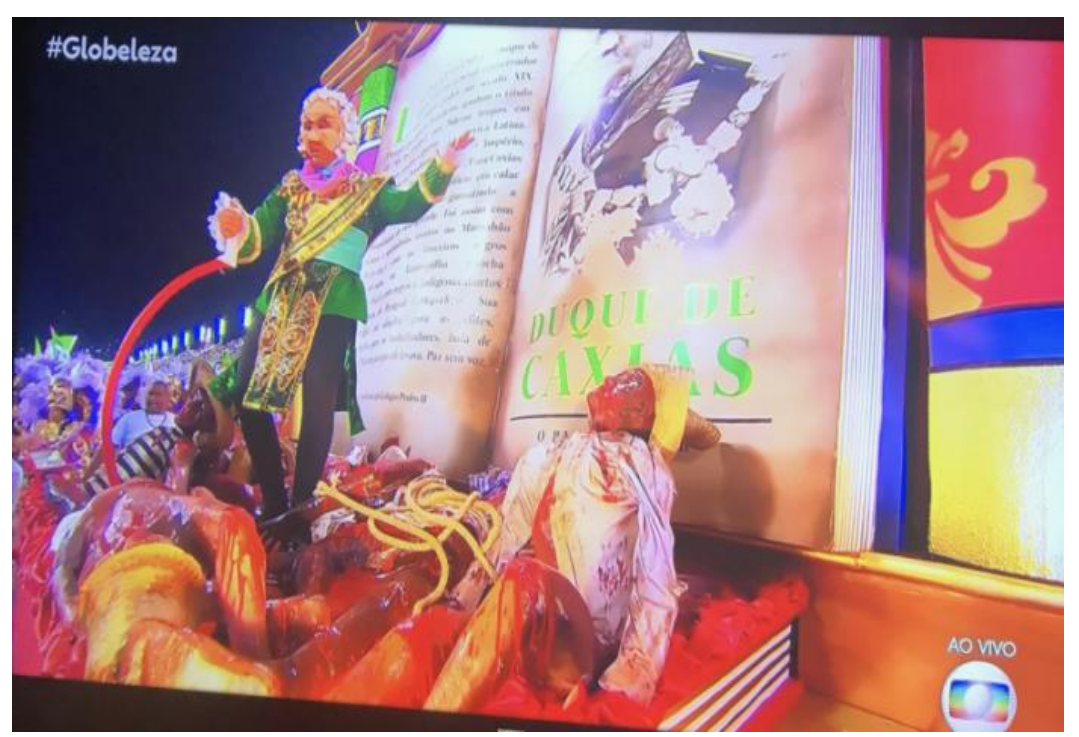

Fonte das 4 (quatro) imagens: Print de tela realizada pelo autor. Desfile das Escolas de Samba do Grupo Especial do Rio de Janeiro (TV GLOBO, 2019).

$\mathrm{Na}$ frente, como destaque principal do carro, a jornalista carioca Hildegard Angel (imagem 2). Ela usa uma réplica do vestido de sua mãe, a estilista Zuzu Angel, em sinal de luto pelo desaparecimento do filho Stuart Angel Jones em 1971. No pescoço, a destaque do carro traz um colar com dezenas de pingentes de cruzes. Era de sua mãe e lembrava os desaparecidos políticos no decorrer dos anos de chumbo no Brasil. Logo atrás, a pichação "Ditadura assassina", numa foto em preto e branco reproduzida nas páginas de um livro gigante. Uma mensagem contundente em resposta à recusa do governo em admitir que houve ditadura no Brasil. É a necropolítica em funcionamento a todo vapor.

Negar a história, borrar a verdade e desinformar são estratégias de governos fascistas. Por isso, a importância do conhecimento e da arte para se opor e resistir ao senso comum e à ignorância. Nessa perspectiva, havia também na alegoria outros livros gigantes em que Professores de Escolas de Ensino Médio e Fundamental puderam reescrever a história de personagens como Duque de Caxias, José de Anchieta e Floriano Peixoto (imagem 3). Estes vieram representados de forma caricata, sambando sob os corpos de mulheres, negros/os e índios/as que mataram ou deixaram morrer (imagem 4).

A alegoria, toda estruturada em livros gigantes, apontam para um caminho: a educação. A escola pode reescrever e ressignificar a história da população brasileira. E é sobre isso que trataremos a seguir.

Rev. Eletrônica Mestr. Educ. Ambient. Rio Grande, Dossiê temático "Imagens: resistências e criações cotidianas", p.368-387, jun. 2020. E-ISSN 1517-1256 


\title{
A história que a história não conta
}

Historicamente, a educação brasileira é caracterizada pela dicotomia elitismo e exclusão. Nessa perspectiva, Saviani (2011), ao investigar as ideias pedagógicas no Brasil, constatou que a educação oferecida para as elites é uma e para as camadas mais populares, outra. Os estudos de Duarte \& Saviani $(2012$, p. 2) se coadunam com tal ideia referente à educação: "o sistema escolar estrutura-se de forma fragmentada, reproduzindo a divisão social e a lógica do mercado. $\mathrm{O}$ acesso ao conhecimento dá-se de maneira profundamente seletiva". Por certo, é importante percebermos a dinâmica dos mecanismos excludentes que conduzem a educação, no intuito de desbaratá-los e contribuir na construção de uma sociedade mais justa.

Ainda que se possa compreender de forma densa a educação elitista e excludente em voga nos dias de hoje, é imprescindível entender essa dinâmica a partir da história. Bittar \& Ferreira Jr. (2009) delinearam a importância de não se segmentar a história. É necessário que ela seja compreendida em sua inteireza, de forma que o presente possa ser percebido não como uma aleatória possibilidade social, mas sim como um projeto que foi arquitetado desde tempos longínquos por homens brancos da elite que se apossaram da educação para utilizá-la como dispositivo de manutenção de seus privilégios em “detrimento de todos" (BUFFA, 1979, p. 42).

A história não narrada e invisível já foi cantada por Bertold Brecht, em seu poema "Perguntas de um trabalhador que lê" ([1935] 2000). Nesses versos, Brecht assinala que para cada grande herói, na sombra de todo grande acontecimento, existem diversas histórias inexploradas, porém importantes para o entendimento dos eventos analisados. No entanto, como o currículo escolar foi historicamente concebido com base nos interesses das classes hegemônicas, sujeitos como mulheres, negros/as, índios/as, gays, lésbicas e transgêneros/as, costumam ser sumariamente apagadas/os dos materiais didáticos. $\mathrm{O}$ trecho a seguir da letra do samba de 2019 da Mangueira explicita muito bem essa ideia de exclusão:

\author{
Brasil, meu dengo \\ A Mangueira chegou \\ Com versos que o livro apagou \\ Desde 1500 tem mais invasão do que descobrimento \\ Tem sangue retinto pisado \\ Atrás do herói emoldurado \\ Mulheres, tamoios, mulatos \\ Eu quero um país que não está no retrato
}

Rev. Eletrônica Mestr. Educ. Ambient. Rio Grande, Dossiê temático "Imagens: resistências e criações cotidianas", p.368-387, jun. 2020. E-ISSN 1517-1256 
Conforme Silva, "questionar a identidade e a diferença como relações de poder significa problematizar os binarismos em torno dos quais elas se organizam" (2007, p.83). Isso nos leva às proposições de Foucault (2014), quando ele corrobora a efetividade da microfísica do poder. Estamos envolvidos numa teia que resulta na produção da diferença, já que fazemos parte da representação do poder numa dimensão micro. Assim, o discurso presente no imaginário social articula identidades e diferenças a estereótipos préconcebidos, relacionando essas pré-concepções ao poder social.

Neste sentido, o desfile da Mangueira, ao propor revelar o visível e o invisível aos olhos da sociedade, pode instigar práticas de mudanças, se pensarmos no contexto escolar. Ao recorrermos ao conceito de cultura engendrado por Williams (1992) como um espectro de sentidos, encontramos base para compreender a escola e a sua articulação com a cultura, no sentido de endossá-la em sua função social de reafirmar as variadas formas de ser, fazer e pensar que integram as ações do cotidiano escolar.

Dessa forma, a junção entre os âmbitos escolar e cultural tornou-se necessária para explicitar a legitimidade de se debater sobre obras constituídas na linguagem audiovisual como uma forma pela qual as pessoas desenvolvem suas próprias representações, como também dos outros e do mundo. Isso, inclusive, reforça as reordenações pelas quais a linguagem vem passando no sentido de se coadunar com a multifacetada possibilidade de diálogo dos sujeitos.

Essa ótica favorece que outros sentidos estéticos e culturais sejam abordados na escola, articulados aos saberes e aos acontecimentos da atualidade e que se amplificam por meio de processos interativos. E, com isso, compreender o quanto a escola e o/a professor/a podem levar em consideração, em seu ofício de ensinar, as expressões advindas da linguagem audiovisual, concebendo-as como mobilizadoras de transformações no modus operandi de ser e estar no mundo.

Nessa perspectiva, é relevante ponderar que, conforme Forquin (1993) é papel da escola subsidiar a construção e conservação da cultura como experiência humana, por meio da prática pedagógica. Assim, há uma simbiose entre educação e cultura, pois a escola, ao planejar um currículo, leva em conta elementos culturais e, nessa direção, os vetores que compõem a cultura da escola são basilares para a valorização de artefatos de diferentes tempos e espaços, os quais se evidenciam envoltos de intencionalidades e sentidos. Ainda sob a ótica de Forquin (1993), na etapa de organização e seleção, próprio do fazer docente, existem unidades que sobrevivem à memória escolar. Todavia, de acordo com o contexto, 
irrompem outros referenciais culturais que sinalizam para outros sentidos, saberes e perspectivas.

Destarte, nessa seleção de conhecimentos que a escola promove, está a sua mais importante ação educativa, uma vez que, ademais haja um conhecimento puramente intelectual, "o sentido último do conhecimento que nos dignifica como sujeitos, é justamente a desinstalação e o espanto que lançam cada ser humano na direção de outros significados que transformam o nosso modo de ser no mundo" (GHEDIN, 2010, p. 143).

Sob esse viés, interpelar a presença na sociedade dos meios de comunicação e, neste caso, da produção audiovisual (mais especificamente, do desfile de uma escola de samba, que é transmitido pela televisão ou internet) e suas reverberações na escola, caracteriza-se como uma das mais relevantes ações a favor da educação, junto a aspectos relacionados às tecnologias de informação e comunicação (TIC), que se apresentam como um dos vetores responsáveis por reformular o papel e a posição do sujeito nas relações discursivas.

Ainda que represente uma conexão entre as imagens do cotidiano, a leitura de imagem provinda do audiovisual (cinema, televisão, vídeo, internet) e a experiência estética realizada em sala de aula, pode constituir um modo significativo e matizado de leitura; pois, ler imagens atualmente está associado à capacidade de leitura também das visualidades que nos circundam e nos constituem, as quais representam não somente a interpretação de imagens, mas também perspectivas de mundo.

Assim, conceber um currículo que atenda a essas singularidades pode atribuir múltiplos olhares acerca do trabalho com imagens em sala de aula, ainda que percebamos que a concepção autoritária das diretrizes propostas hierarquicamente reflita na forma com a qual o currículo é implementado e veiculado no contexto escolar da atualidade.

Por isso, quando, no último setor do desfile, grandes livros reescritos por professores (imagem 3), seguidos da ala que fecha o cortejo, com bandeiras exaltando figuras importantes da cultura popular, como Carolina Maria de Jesus, Jamelão, Nelson Sargento e Marielle Franco, configura-se como uma resposta à classe conservadora, guiada pela necropolítica, que busca, de forma sistemática, silenciar identidades historicamente subalternizadas sob o pretexto de uma suposta e impostora ideia de uma escola neutra e sem partido.

E não parou por aí: em tempos de ataque aos estudos de gênero e à luta do movimento feminista e antirracista, sobretudo no âmbito da educação, a agremiação deu destaque às narrativas de mulheres negras guerreiras que, de alguma forma, lutaram por Rev. Eletrônica Mestr. Educ. Ambient. Rio Grande, Dossiê temático "Imagens: resistências e criações cotidianas", p.368-387, jun. 2020. E-ISSN 1517-1256 
uma nação livre e igualitária: além de Marielle Franco, foram retratadas Luiza Mahin, Dandara dos Palmares, Maria Felipa, Esperança Garcia, Aqualtune, Tereza de Benguela, dentre outras.

Imagem 5: Marielle Franco representada em uma das bandeiras que encerra o desfile

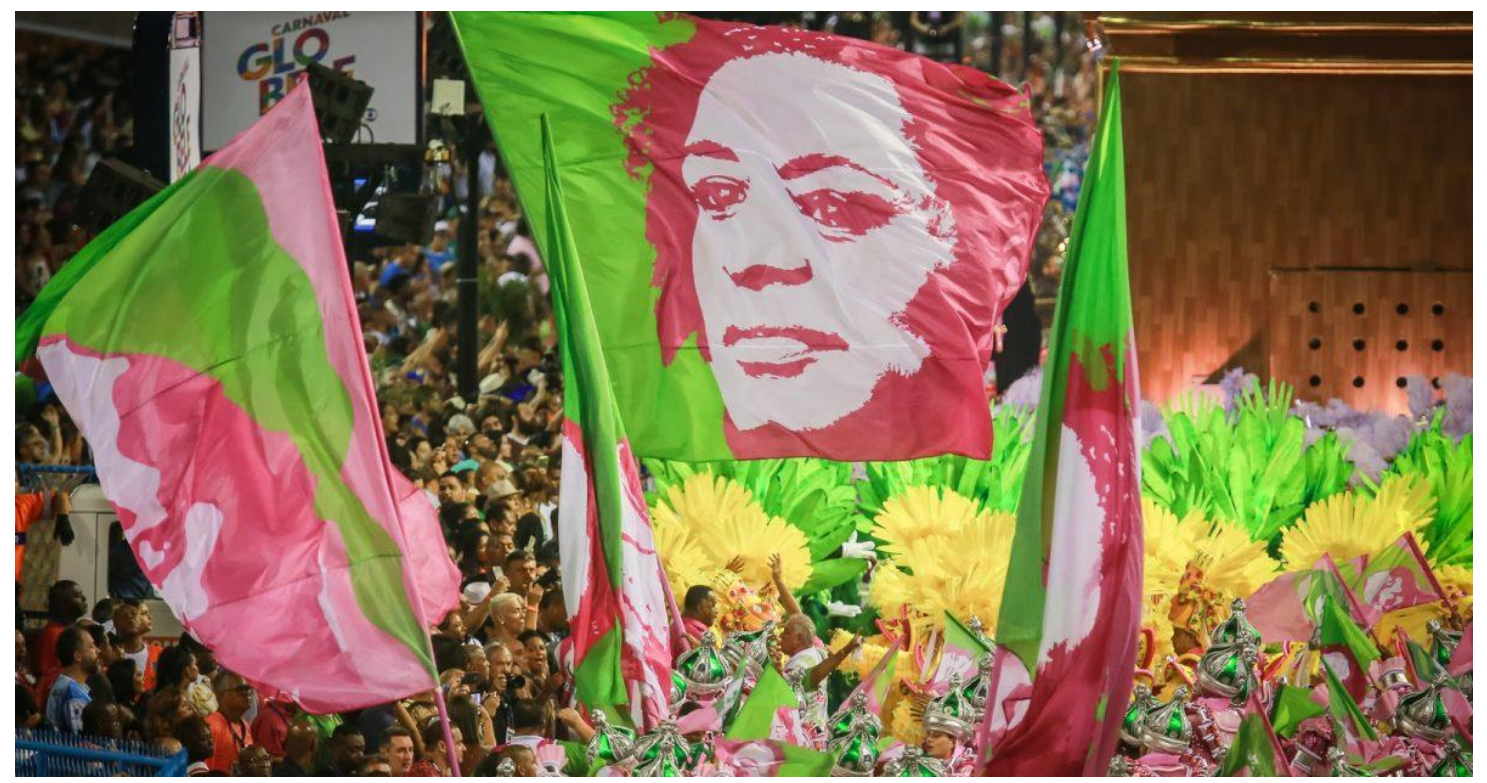

Fonte: Print de tela realizada pelo autor. Desfile das Escolas de Samba do Grupo Especial do Rio de Janeiro (TV GLOBO, 2019).

Desta forma, explicitar a leitura de imagem de um desfile televisionado representa aqui não apenas uma justificativa para se debater sobre imagens para além do universo da arte - ou quaisquer outros formatos contemporâneos de manifestação visual produzidos pelas tecnologias digitais -, mas também uma possibilidade de interpretá-las como um complexo semântico condutor de diálogos entre sujeitos.

Em concordância com Quintana e Dussel (2012), o trabalho com imagem na escola deve ser tencionado sob o crivo da criticidade. Assim sendo, teremos como lê-la e como vê-la. É nessa perspectiva que os autores salientam que é preciso captar não somente o óbvio, mas também o obtuso. Tal necessidade configura-se devido ao risco que o texto icônico corre de se dissipar ou se transformar em outras "coisas", ao ser submetido ao olhar (muitas vezes, previamente projetado) das regras escolares.

Por outro lado, uma educação aberta à diversidade pode permitir a ressignificação constante do olhar que temos a respeito dos outros. Dessa forma, o outro é algo diametralmente novo que desestabiliza as certezas e a linearidade do mundo.

Assim começa o samba da Mangueira:

Mangueira, tira a poeira dos porões

$\hat{O}$, abre alas pros teus heróis de barracões

Rev. Eletrônica Mestr. Educ. Ambient. Rio Grande, Dossiê temático "Imagens: resistências e criações cotidianas", p.368-387, jun. 2020. E-ISSN 1517-1256 
Dos Brasis que se faz um país de Lecis, Jamelões

São verde e rosa, as multidões

Ao tentar abalar essa estabilidade podemos deixar de projetar no outro o que somos, o que queremos ou buscamos. Larrosa (2007) nos motiva a refletir sobre uma pedagogia da imagem que examina uma forma de perspectiva sobre o mundo e sobre a experiência humana (turva, imprecisa, obtusa). Imagens que conduzam mais a perguntas do que a respostas; imagens que provocam reflexões sobre a realidade, mas que demandam de atenção e tempo, esquivando-se das armadilhas dos imediatismos e das verdades absolutas. Para tal, torna-se necessário tirar "a poeira dos porões" dos diversos mistérios que envolvem a singularidade do outro. Se o compreendermos numa dinâmica de continuidade, poderemos romper com a ideia de temporalidade, tal qual se apresenta nos currículos atuais. Como consequência dessa possibilidade de cisão, o tempo poderá estar sempre nos convidando a um novo começo e aos "heróis de barracões".

\section{Brasil chegou a vez de ouvir as Marias, Mahins, Marielles, Malês}

Vivemos novamente numa época em que o Estado tenta aplacar as memórias da população, incentiva a proibição de posicionamentos críticos e ataca o entendimento das nossas próprias narrativas. Porém, dessa vez, ecoa o grito do samba. Escutamos os gritos que no passado foram amordaçados.

O samba enredo da Mangueira configura-se num clamor dessa batalha incessante pela visibilidade. Logo no início do desfile, quando a criança - uma menina negra - abre um livro e em suas páginas está escrito "Presente", a Estação Primeira não evoca somente Marielle Franco, mas apresenta também uma contundente reflexão de que as narrativas de negros/as, pobres, índios/as e LGBTQI+ se fazem presente, e que os interditos e as invisibilidades do passado não podem mais ser toleradas. Os segmentos que foram "sobrepujados" em embates ou "aniquilados" pela triagem histórica são rememorados, de modo que seus gritos puderam ser ouvidos em plena Marquês de Sapucaí.

No âmbito da Educação, a aula que a Mangueira nos deu nos 71 minutos de desfile propõe justamente a ruptura com a rigidez institucional, de modo que aproxime o currículo da realidade. Procurando deslindar o invisível aos olhos, e compreendendo os movimentos paradoxais que ocorrem no confronto com o visível. Para consubstanciar essa proposta, faz-se necessário romper com paradigmas unidimensionais do conhecimento, do/a 
educador/a e do/a educando/a, concebendo-os/as na sua integralidade, através das múltiplas relações que se estabelece com o mundo.

É nesse viés que Quintana e Dussel (2012) esclarecem que a imagem não pode ser interpretada como uma abertura para o mundo, mas como um esconderijo, quando dizem que o texto icônico não nos mostra apenas o que está na superfície do olhar, mas, principalmente, sinaliza para o que está escondido por debaixo do tecido da própria imagem.

Ao apresentar a história de Marielles, Zumbis, Dandaras e Cunhambebes, a agremiação nos convida a olhar para as concepções de currículo que permeiam o meio educacional, com lentes que permitam olhar essas imagens para além da névoa. E experimentando e abrindo-se para os movimentos implementados no cotidiano sem medo de arriscar; e aventurando e partilhando com outras pessoas afetos, sensações, desejos, aprendizagens...

E quando o sujeito entoa o samba, essa dinâmica acontece. Não apenas na Sapucaí, mas também no lar, no trabalho, na rua, na escola. A transmissão pela oralidade dessas narrativas através das imagens e do samba permite que no presente e no futuro outros contadores de histórias possam recuperar a luta da população que foi negligenciada pelos ditames oficiais e, mais do que isso, possam legitimar e continuar as pautas que foram obstruídas pelos "famigerados vencedores".

\section{Referências}

BENJAMIN, Walter. A arte de contar histórias. Tradução de Georg Otte, Marcelo Backes e Patrícia Lavelle. São Paulo: Hedra, 2018.

BENJAMIN, Walter. Magia e técnica, arte e política: ensaios sobre literatura e história da cultura. Tradução de Sérgio Paulo Rouanet. 3. ed. São Paulo: Brasiliense, 1987.

BRECHT, B. Poemas 1913-1956. Tradução de Paulo César de Souza. São Paulo: Editora 34, 2000.

BITTAR, Marisa; FERREIRA JR., Amarílio. História, epistemologia marxista e pesquisa educacional brasileira. Educação e Sociedade, Campinas, v. 30, n. 107, p. 489 - 511, maio/ago, 2009.

BUFFA, Ester. Ideologias em conflito: escola pública e escola privada. São Paulo: Cortez \& Moraes, 1979.

CARVALHO, Claudio. Os sambas de 2019 por Cláudio Carvalho. Sambario. Rio de Janeiro, 2018. Disponível em:

Rev. Eletrônica Mestr. Educ. Ambient. Rio Grande, Dossiê temático "Imagens: resistências e criações cotidianas", p.368-387, jun. 2020. E-ISSN 1517-1256 
http://www.sambariocarnaval.com/index.php?sambando=2019claudio. Acesso em 13 abr. 2020.

DESFILE DO GRUPO ESPECIAL DO RIO DE JANEIRO. Estação Primeira de Mangueira. Rio de Janeiro: Globo, 4 mar. 2019. Programa de TV. Disponível em: https://www.youtube.com/watch?v=scKZBmi3-F0. Acesso em 14 set. 2019.

FONSECA, Carlos A. Os sambas de 2019 por Carlos Alberto Fonseca. Sambario, Rio de Janeiro, 2018. Disponível em:

http://www.sambariocarnaval.com/index.php?sambando=2019carlos. Acesso em 13 abr. 2020.

FORQUIN, Jean-Claude. Escola e Cultura: as bases sociais e epistemológicas do conhecimento escolar. TraduçãoGuacira Lopes Louro. Porto Alegre: Artes Médicas, 1993.

FOUCAULT, Michel. Em defesa da sociedade. Tradução de Maria Ermantina Galvão. São Paulo: Martins Fontes, 2000.

FOUCAULT, Michel. Microfísica do poder. Tradução de Roberto Machado. 28. ed., Rio de Janeiro: Edições Graal, 2014.

FRONT LINE DEFENDERS. Basta de assassinatos. Dublin: Front Line, 2018.

Disponível em:

https://www.frontlinedefenders.org/sites/default/files/stop_the_killings_full_report_portug uese.pdf. Acesso em 13 abr. 2020.

GHEDIN, Evandro. Professor reflexivo. Da alienação técnica à autonomia crítica. In: PIMENTA, Selma G.; GHEDIN, Evandro. Professor reflexivo no Brasil: gênese e crítica de um conceito. 6. ed.São Paulo: Cortez, 2010, p.129-150.

LARROSA, Jorge. Lasimágenes de la vida y la vida de lasimágenes: tres notas sobre el cine y la educación de la mirada. Educação \& Realidade, Porto Alegre, v. 32, n. 2, p. 7 22, jul/dez. 2007.

LIESA. Abre alas: Segunda. Rio de Janeiro: LIESA, 2019.

MANGUEIRA ANUNCIA SAMBA-ENREDO EM HOMENAGEM À MARIELLE E MULHERES QUE LUTARAM POR DIREITOS. Geledés. São Paulo, 16 out. 2018. Disponível em: https://www.geledes.org.br/mangueira-anuncia-samba-enredo-emhomenagem-marielle-e-mulheres-que-lutaram-por-direitos. Acesso em 13 abr. 2020.

\section{MANGUEIRA DIVULGA SAMBA-ENREDO QUE HOMENAGEARÁ MARIELLE} FRANCO. O Povo. Fortaleza, 14 out. 2018. Disponível em:

https://www.opovo.com.br/noticias/brasil/2018/10/mangueira-samba-enredo-do-carnaval2019-homenagem-marielle-franco.html. Acesso em 13 abr. 2020.

MANGUEIRA ESCOLHE SAMBA DO CARNAVAL DE 2019 E HOMENAGEIA MARIELLE FRANCO. G1 Rio. Rio de Janeiro. 14 out. 2018. Disponível em: https://g1.globo.com/rj/rio-de-janeiro/carnaval/2019/noticia/2018/10/14/mangueira- 
escolhe-samba-do-carnaval-de-2019-e-homenageia-marielle-franco.ghtml. Acesso em 13 abr. 2020.

MANGUEIRA FAZ HOMENAGEM A MARIELLE EM SAMBA-ENREDO DE 2019. Diário de Pernambuco, Recife, 14 out. 2018. Disponível em: https://www.diariodepernambuco.com.br/noticia/viver/2018/10/mangueira-fazhomenagem-a-marielle-fara-em-samba-enredo-de-2019.html. Acesso em 13 abr. 2020.

MANGUEIRA HOMENAGEIA MARIELLE FRANCO EM LETRA DE SAMBA DO CARNAVAL 2019. JC Online, Rio de Janeiro, 15 out. 2018. Disponível em: https://jconline.ne10.uol.com.br/canal/cultura/noticia/2018/10/14/mangueira-homenageiamarielle-franco-em-letra-de-samba-do-carnaval-2019-358322.php. Acesso em 13 abr. 2020.

MARCOS, João. Os sambas de 2019 por João Marcos. Sambario. Rio de Janeiro, 2018. Disponível em: http://www.sambariocarnaval.com/index.php?sambando=2019joao. Acesso em 28 set. 2019.

MBEMBE, Achille. Tradução de Renata Santini. Necropolítica. São Paulo: N-1 Edições, 2018.

QUINTANA, Ángel; DUSSEL, Inês. Entre lo obvio y lo obtuso: notas sobre cine y educación. Conversación entre Ángel Quintana e InésDussel. In: Educación, imágenes y medios. Buenos Aires: FLACSO, 2012.

SAVIANI, Demerval. História das ideias pedagógicas no Brasil. 3. ed. Campinas: Autores Associados, 2011.

SAVIANI, Demerval; DUARTE, Newton (orgs). Pedagogia histórico crítica e luta de classes na educação escolar. Campinas: Autores Associados, 2012.

SILVA, Tomaz Tadeu. Documentos de identidade: uma introdução às teorias do currículo. São Paulo: Autêntica, 2007.

SOARES, Rafael. Análise dos Sambas-Enredo do Grupo Especial do RJ para o Carnaval 2019. ArteCult: arte, conhecimento e transformação. Rio de Janeiro, 2019. Disponível em: http://artecult.com/analise-dos-sambas-de-enredo-carnaval-2019-rj. Acesso em 13 abr. 2020 .

TESI, Rômulo. Com 'samba da Marielle', Mangueira exaltará heróis esquecidos nas placas de rua, Setor 1/Band, São Paulo, 15 out. 2018. Disponível em:

https://setor1.band.uol.com.br/com-samba-da-marielle-mangueira-exaltara-heroisesquecidos-que-nao-ganharam-placas-nas-ruas. Acesso em 13 abr. 2020.

VIEIRA, Leandro. Mangueira divulga seu enredo para 2019. Site Oficial da Estação Primeira de Mangueira. 2018. Disponível em: http://www.mangueira.com.br/noticiadetalhada/993. Acesso em 13 abr. 2020.

WILLIAMS, Raymond.Cultura. Tradução deLólio Lourenço de Oliveira. Rio de Janeiro: Paz e Terra, 1992.

Rev. Eletrônica Mestr. Educ. Ambient. Rio Grande, Dossiê temático "Imagens: resistências e criações cotidianas", p.368-387, jun. 2020. E-ISSN 1517-1256 
Submetido em: 30-04-2020.

Publicado em: 01-07-2020.

Rev. Eletrônica Mestr. Educ. Ambient. Rio Grande, Dossiê temático "Imagens: resistências e criações cotidianas", p.368-387, jun. 2020. E-ISSN 1517-1256 